\title{
Changes Needed in Basic Biomedical Sciences Teaching in Cuban Medical Schools
}

\author{
Marta Pernas MD MS, Lourdes G. Arencibia MD MS, Mayra Garí MD
}

\begin{abstract}
In the 20th century, the basic biomedical sciences (particularly anatomy, histology, embryology, physiology and biochemistry) were taught predominantly in the first semesters of Cuban medical education, with differing curricular connections between these and the clinical sciences. Establishment of the University Polyclinic Program in 2004 laid the foundation for integration of basic biomedical sciences into a transdisciplinary unit designated morphophysiology.
\end{abstract}

This paper argues for improvements in this curricular unit and in its coordination with family medicine in the first semesters of medical training, complemented by integration of basic biomedical sciences into family medicine clinical courses throughout the remainder of the six-year curriculum.

KEYWORDS Medical laboratory science, medical clinical science, medical education, curriculum, biological science disciplines, interdisciplinary communication, transfer of learning, Cuba

\section{BASIC MEDICAL SCIENCES IN 20TH-CENTURY CUBAN MEDICAL EDUCATION}

Early in the last century, two important events in higher education in the Americas had different degrees of impact on Cuban medical education. The first was Abraham Flexner's 1910 report on quality of medical training in the United States and Canada,[1] which had particular influence on curriculum. The second was Argentina's Cordoba Reform of 1918, which had a significant impact on university and political life in Cuba,[2] but less influence on curricular reform.[3]

Although the Flexner report recommended and presaged a shift in health care models towards more focus on health promotion and disease prevention, [1] the main influence of his work on 20thcentury curricula in Cuba and elsewhere was his insistence on the need to strengthen the biomedical scientific foundation of medical education. This was reflected in a curricular structure and content oriented toward hospital-based training emphasizing curative treatment for individual patients.[4] As a result, the basic biomedical sciences became the foundation of medical school curricula, offered as independent courses in the first years of training, as in the case of anatomy, histology, embryology, physiology and biochemistry.

In the 20th century, Cuba implemented curricular reforms in 1900 , 1919, 1924, 1928, 1934, 1937 and 1941-42.[3] Basic general and basic biomedical sciences constituted between $24 \%$ and $50 \%$ of total curricular units.

Starting in 1959, additional curricular changes were made, with the disciplinary structure of the basic biomedical sciences predominating. These courses were concentrated in the first two years of the six-year academic program, disconnected from the clinical sciences.[3,5,6]
From the 1960 s to the early 1980 s, rapid and profound changes took place in the strategy for training physicians and other health professionals in Cuba.[5] For medical education in particular, these can be divided into three phases:[6]

- With the 1962 university reform, teaching labs (practicals) increased in basic biomedical and basic clinical sciences (such as pathology), and students in their latter years of training were provided experience in clinical settings. Separation between basic biomedical sciences and clinical subjects persisted.

- Between 1971 and 1977, service learning was introduced at the primary care level for first- and second-year students, in a curriculum integrated around the longitudinal unit Man [sic] and his Environment.

- Beginning in 1978, a new subject-based curriculum was implemented, continuing through 1983. The basic biomedical sciences remained independent disciplines, separated from the clinical sciences and offered in different phases of the academic program.

In 1984, the national public health system adopted a new primary health care (PHC) model, the Family Doctor and Nurse Program. [7] Family medicine was established as a specialty and a new undergraduate curriculum was implemented to train general physicians, [8] in which family medicine was included as an academic discipline and the basic biomedical sciences continued to be offered as independent (although coordinated) courses, taught with others during the first three semesters (Table 1).

Table 1: Cuban medical curriculum: first three semesters (academic years 1984-1985 through 2005-2006)

\begin{tabular}{|c|c|c|}
\hline 1st semester & 2nd semester & 3rd semester \\
\hline Anatomy I & Anatomy II & Anatomy III \\
\hline Histology I & Histology II & Histology III \\
\hline Embryology I & Physiology I & Embryology II \\
\hline $\begin{array}{l}\text { Cellular and Molecular } \\
\text { Biology (biochemistry) }\end{array}$ & $\begin{array}{l}\text { Intermediate Metabo- } \\
\text { lism and its Regula- } \\
\text { tion (biochemistry) }\end{array}$ & Physiology II \\
\hline Physical Education I & Physical Education II & $\begin{array}{l}\text { Physical } \\
\text { Education III }\end{array}$ \\
\hline English I & English II & English III \\
\hline $\begin{array}{l}\text { Introduction to } \\
\text { Family Medicine }\end{array}$ & Medical Informatics I & \\
\hline $\begin{array}{l}\text { Philosophy and } \\
\text { Health I }\end{array}$ & $\begin{array}{l}\text { Philosophy and } \\
\text { Health II }\end{array}$ & \\
\hline
\end{tabular}

Source: Medical University of Havana. National Medical Curriculum Commission

This curriculum was in effect for over 25 years, with some improvements, primarily the expansion of family medicine as a discipline, as more PHC clinical teaching sites were developed and accredited.[9]

Conceptual transformations have occurred in higher medical education in recent decades worldwide and in Cuba, resulting from scientific and technical development, as well as organiza- 
tional changes in medical services and practice. In Cuba's case, these transformations also respond to the need identified by the Ministry of Public Health (MINSAP, the Spanish acronym) for primary care physician training in Cuba and in countries requesting Cuban collaboration. Given this new environment, we argue for a restructuring of basic biomedical sciences content in Cuban medical education into two components:

1. Essential content, organized within morphophysiology, in horizontal interdisciplinary coordination with the main integrating discipline of family medicine, from the first semesters of the six-year academic program; and

2. Content chosen for its relevance and integrated into clinical family medicine subjects, where it has potential for application to specific diagnostic or therapeutic problems in clinical settings in the later years of study.

\section{THE UNIVERSITY POLYCLINIC PROGRAM AND ITS INFLUENCE ON BASIC BIOMEDICAL SCIENCES' CURRICULAR STRUCTURE}

While the 1984 curriculum remains relevant in light of today's international quality standards for medical education in terms of professional competencies,[10] the same is not true of basic biomedical sciences. Both basic and quality development standards established in 2003 by the World Federation of Medical Education[10] indicate a need to improve teaching of basic biomedical sciences, for greater relevance to needs of the professional in training and to make it more reflective of current trends in university education, including integration of essential content in undergraduate programs, with continuity maintained in graduate-level studies.

In 2004, MINSAP identified the need to educate more primary care physicians and related health professionals for Cuba and other developing countries, and determined that their training should be grounded more firmly in the community, their future arena of practice. Thus, a package of curriculum changes was implemented under the rubric of the University Polyclinic Program (PPU, the Spanish acronym).[11] In the PPU model, physician training in PHC settings is considered essential from year one, with family medicine specialists playing a central role as accredited instructors and guides. Initially, the original curriculum structure was maintained for the basic medical sciences, with separate courses in anatomy, histology, embryology, biochemistry and physiology.

Several difficulties where revealed in early assessment of the PPU experience teaching basic biomedical sciences in the new settings-community-based polyclinics.[12] Additionally, experiences under way in Venezuela, where Cuban professionals were training physicians,[13] and in Cuba, with university-level education for nursing personnel,[14] led to modifications in teaching basic biomedical sciences subjects. Starting in the 2006-2007 academic year, these were integrated in a new academic discipline, morphophysiology, with general objectives similar to those of the original basic biomedical sciences courses: contribute to educating well-rounded professionals, and develop their scientific reasoning and ability to provide the evidence base for clinical decisions.

Morphophysiology was designed with a transdisciplinary approach for coherent integration of anatomy, histology, embryology, bio- chemistry and physiology content, selected and organized to eliminate gaps in coordination among these subjects from which it arose. It explores body systems through the lens of each of the traditional basic biomedical sciences in a comprehensive way, integrating structure and function in order for students to better comprehend how the body actually works, thus increasing relevance to professional competencies and, with its more logical learning sequence, making content more accessible to students. $[14,15]$

Morphophysiology also incorporated modifications in medical education, primarily in the choice of teaching-learning aids (taking advantage of new technology) and organizational formats that departed from the traditional "lectures and labs." Along with the development of educational activities in PHC-level institutions, other important changes shifted the teaching process' traditional features, such as the focus on the professor as the main source of knowledge, the use of cadavers, and laboratory practicals for various subjects.

Laboratory practicals were replaced by other activities thatbesides contributing to development of logical thinking, mastery of scientific method, and fulfilling an important integrating rolewere offered in interdisciplinary coordination with family medicine. In these service-learning practicals, students apply morphophysiology to the clinical demands of their family medicine courses, taught in the first three semesters, thus seeing its relevance to disease prevention and health promotion with healthy people as well as in patient care.[13]

In the 2010-2011 academic year, further adjustments were made under the leadership of the National Medical Curriculum Commission (CNC, the Spanish acronym), the MINSAP academic unit responsible for design and implementation of curriculum changes. The intent was to improve interdisciplinary coordination between morphophysiology and family medicine courses[16] to promote more effective integration of basic biomedical sciences content into family medicine education in clinical settings. Table 2 reflects that each of the first three semesters now includes family medicine subjects as well as morphophysiology, thus strengthening the role of family medicine as the backbone and integrative discipline of undergraduate medical education, its courses now present throughout all six years of the curriculum.

Table 2: Cuban medical curriculum: first three semesters (academic year 2010-2011)

\begin{tabular}{|c|c|c|}
\hline 1st semester & 2nd semester & 3rd semester \\
\hline Morphophysiology I & Morphophysiology III & Morphophysiology V \\
\hline Morphophysiology II & Morphophysiology IV & Morphophysiology VI \\
\hline $\begin{array}{l}\text { Introduction to Family } \\
\text { Medicine* }\end{array}$ & Health Promotion* & Disease Prevention* \\
\hline $\begin{array}{l}\text { Philosophy and } \\
\text { Society I }\end{array}$ & $\begin{array}{l}\text { Philosophy and } \\
\text { Society II }\end{array}$ & $\begin{array}{l}\text { Methodology of } \\
\text { Research and } \\
\text { Statistics }\end{array}$ \\
\hline Physical Education I & Physical Education II & Physical Education III \\
\hline \multirow[t]{3}{*}{ English I } & English II & English III \\
\hline & Medical Informatics I & History of Cuba I \\
\hline & & Elective \\
\hline
\end{tabular}

Source: Medical University of Havana. Physician Training Curriculum, 2010

* Family medicine courses 
As with all change, resistance has been encountered among some students and their families (perhaps due to allegiance to tradition or recognition of the prestige and experience of professors specializing in basic biomedical sciences, or for other reasons that merit further research). Some faculty have also resisted changes, while others are studying the development of the new approach and looking for ways to improve not only its design but also its application.[11,13,14,17,18]

\section{PROPOSED CURRICULAR CHANGES}

Evolution of professional paradigms in response to changes in individual and population health have prompted reconfiguration of the physician's mission.[19] In turn, the sociobiological focus of modern medicine requires rethinking the role traditionally filled by basic biomedical sciences courses in developing students' scientific thinking: why not share that role with relevant social sciences (medical sociology, for example), contributing to a more current and relevant approach to the scientific method within the comprehensive, integrated social paradigm of medical education and practice?

What's more, in medicine, scientific reasoning is expressed in clinical and epidemiological methods within a social context, making social contextualization of its application an essential methodological component that strengthens curricular relevance. This contextualized application is the basis for the changes we propose in the structure of basic biomedical sciences teaching in medicine.

The interdisciplinary nature of morphophysiology provides a starting point and partial solution to a problem that dates from the original version of this curriculum over 25 years ago, which affirmed the need for more interdisciplinary integration and coordination. [8] However, these do not take place in a vacuum: as we have discussed, basic biomedical sciences should be studied in an applied context, facilitating deeper understanding of content and greater ability to use what is learned. Morphophysiology's transdisciplinary nature permits active-and, we believe, essentialcoordination with the all-important family medicine courses also taught in medicine's initial semesters.

Viewed from another perspective: in order for Cuban medical education to continue to meet the World Federation for Medical Education (WFME) standards,[10] two conditions must be met: basic biomedical sciences curricular content must be expanded in response to rapid growth and advancements in scientific knowledge (basic standard), and these subjects must be integrated into the clinical disciplines (quality development standard).[10]

We contend that, for these conditions to be fulfilled in an academic program whose backbone is family medicine, changes in basic biomedical sciences teaching should focus on two systemicallyrelated components that involve redefinition of the objectives of morphophysiology, so that its courses continue to be offered early in medical training, but not exclusively so, with differing goals at different stages of medical education. In short, students should encounter basic medical sciences throughout their learning experience. Thus:

- The objective of morphophysiology in the first years would be not only to contribute to students' general professional competencies, but also to provide them with the scientific understanding of the normal functioning of the human body necessary for family medicine courses in the first semesters that emphasize health promotion and disease prevention.

- The objective of including morphophysiology as a complement to family medicine in the ensuing years would be to select relevant and timely content to be integrated into clinical family medicine courses to inform diagnostic approaches and evidence-based treatment decisions, breadth and depth to be determined by family medicine objectives.

In essence, the goal is to increase basic biomedical sciences content in the program, with opportune and relevant insertion in keeping with the current curriculum's disciplinary structure; that is, systematized in the discipline of morphophysiology in the first three semesters of medical training, as currently in effect, and integrated in family medicine courses in all remaining semesters throughout the six years of study.

With today's rapid obsolescence of scientific knowledge, especially in the basic biomedical sciences, it is easy to see the futility of concentrating morphophysiology material in the first few semesters-thus also imposing greater complexity at the start of medical studies without knowledge transfer to clinical learning.[20,21] Not only is unapplied knowledge soon forgotten, but when students finally are able to see its relevance in their clinical years, the basic medical sciences they once learned may already be obsolete.

With the approach we propose, the program's focus on the basic biomedical sciences throughout means that classroom time in general morphophysiology courses could be reduced in the first three semesters, leaving more available for family medicine courses in those semesters, enhancing the role of family medicine as the principal integrating discipline.

Concerning laboratory practicals: future modifications of morphophysiology should analyze their importance and reintroduce those that contribute to developing the professional profile of the physician being trained, through integration of basic courses and clinical activities.

Clearly, modifying the structure of basic biomedical sciences content in the medical program and changing laboratory practicals is a complex task. It calls for experts in basic biomedical sciences and family medicine, as well as in curriculum development and assessment. Methodological referents include the professional model, family medicine's guiding role as primary integrating discipline, and the importance of basic biomedical sciences and other sociomedical sciences as the scientific foundation for professional performance of the general physician projected in the curriculum. The purpose of this paper is not to examine detailed content or structure, but rather to emphasize that curriculum reform should be the result of a coordinated interdisciplinary effort not yet seen in Cuba, or at least not made available to the $\mathrm{CNC}$.

\section{CONCLUSIONS}

After the PPU's establishment in 2004, a transition began toward integration of the basic biomedical sciences into the single discipline of morphophysiology, with more precise identification of essential required content and greater interdisciplinary coordination with family medicine in the medical program's first semesters. Our proposal is to further this process and improve medical training by integrating relevant basic biomedical sciences 
content in family medicine courses throughout the entire sixyear program.

Our proposal is compatible with the current medical education disciplinary structure and requires design, application and evaluation to judge its effectiveness in practice. However, we can predict several direct benefits of its application that include: feasibility of compliance with WFME standards (expansion of basic biomedical sciences and their integration with clinical sciences), reduction of morphophysiology course difficulty and decreased workload in the initial phase of the academic program, and, especially important, use of basic medical sciences as a foundation for timely application of knowledge and scientific reasoning to patient care, diagnostic decision-making and treatment. $-1 /$ -

\section{REFERENCES}

1. Flexner A. Medical education in the United States and Canada: a report to the Carnegie Foundation for the Advancement of Teaching. New York: Carnegie Foundation for the Advancement of Teaching; 1910. 346 p.

2. Delgado G. La Revolución Universitaria de 1923: su repercusión en los estudios de la Escuela de Medicina. In: La Salud Pública y la juventud en el pensamiento del "Che" Guevara. Cuadernos de Historia de la Salud Pública No 83. Havana: Editorial de Ciencias Médicas; 1997. p. 121-32. Spanish.

3. Delgado G. Planes de estudio de Medicina vigentes en la Universidad de La Habana de 1899 a 1958. In: Historia de la Enseñanza Superior de la Medicina en Cuba (1900-1962). Cuadernos de Historia de la Salud Pública. No 105. Havana: Editorial de Ciencias Médicas; 2009 Jan-Jun. p. 7-41. Spanish.

4. Vicedo A. Abraham Flexner, pionero de la Educación Médica. Rev Cubana Educ Méd Super. 2002;16(2):156-63. Spanish.

5. Ilizástigui F. La ciencia, la clínica y el proceso docente educativo. In: Salud, Medicina y Educación Médica. Havana: Editorial de Ciencias Médicas; 1985. p. 179-240. Spanish.

6. Ilizástigui F. Antecedentes de la combinación del estudio y el trabajo en la formación del médico en Cuba. Aplicación de este principio en el actual plan de estudio. In: Salud, Medicina y Educación Médica. Havana: Editorial de Ciencias Médicas; 1985. p. 366-71. Spanish.

7. Sánchez L, Amaro MC. La Salud Pública en Cuba. In: Alvarez R, editor. Temas de Medicina General Integral. Havana: Editorial de Ciencias Médicas; 2001. p. 1-6. Spanish.

8. Ilizástigui Dupuy F, Douglas R. La formación del Médico General Básico en Cuba. Educ Méd Salud. 1993;27(2):189-205. Spanish.

9. Vela J, Fernández JA, Álvarez R. Política de formación médica para la atención primaria de salud y el papel de la asignatura Medicina General Integral en el currículo. Rev Cubana Educ Méd Super [Internet]. 2012 [cited 2012 Apr
26];26(2). Available from: http://www.ems.sld.cu/ index.php/ems/article/view/30/26. Spanish.

10. World Federation of Medical Education. Basic Medical Education: WFME Global Standards for Quality Improvement [Internet]. Copenhagen: WFME; 2003 [cited 2011 Jul 26]. Available from: http://www.wfme.org/standards/bme

11. Damiani Cavero JS. La enseñanza de las ciencias básicas biomédicas y el proyecto del policlínico universitario desde la perspectiva de la comunicación educativa [thesis]. Havana: Centro de Perfeccionamiento de la Educación Superior (CEPES); 2008. Spanish.

12. Loynaz CS. Evaluación de la estrategia educativa para la formación del médico general básico en la atención primaria de salud [thesis]. Havana: National School of Public Health (CU); 2005. Spanish.

13. Gutiérrez A. Áreas de integración para vincular la Morfofisiología Humana con la medicina familiar. EDUMECENTRO. 2009;1(1):34-9. Spanish.

14. Pernas M, Uriarte O. Inter y transdisciplinariedad de las Ciencias Básicas en el nuevo modelo de formación de enfermeros [Internet]. Rev Cubana Enfermería. 2010 [cited 2011 Nov 13];26(2). Available from: http://bvs.sld.cu:80/revistas/enf/ vol26_2_10/enf08210.htm. Spanish.

15. Perera C, Rodríguez I, Iglesias BZ, Pomares E. Histología I y Biología Celular y Molecular como antecedentes del proyecto de programa de Morfofisiología I [Internet]. Rev Haban Cienc Méd. 2008 Jul-Sep [cited 2012 Apr 26];7(3). Available from: http://scielo.sld .cu/scielo.php?script=sci arttext\&pid=S1729 $-519 X 2008000300011 \&$ Ing=es. Spanish.

16. Indicaciones del curso escolar 2010-2011. Havana: Ministry of Public Health (CU). 2010 Aug. Spanish

17. Hernández LJ, López D. La implementación del Modelo Policlínico Universitario, un reto para la Universalización. EDUMECENTRO. 2009;1(2):11-4. Spanish.

18. Enríquez JO, Mendoza T, Carbó JE. Acercamiento a la enseñanza problémica como alternativa metodológica viable en la Educación Médica Superior. EDUMECENTRO. 2009; 1(2):36-40. Spanish.

19. Fernández JA. Los paradigmas médicos y la práctica de la medicina clínica. Boletín Ateneo "Juan César García”. 1996;4(1-2):72-8. Spanish.

20. Perkins DN, Salomon G. Teaching for Transfer [Internet]. Educational Leadership. 1988 Sep [cited 2009 Sep 9];22-34. Available from: http:// www.ascd.org/ASCD/pdf/journals/ed_lead/ el_198809_perkins.pdf

21. Bolander K, Lonka K, Josephson A. How do medical teachers address the problem of transfer? Adv Health Sci Educ. 2008 Aug;13(3):345-60.

\section{THE AUTHORS}

Marta Pernas Gómez (Corresponding author: mpernas@infomed.sld.cu), physician specializing in normal and pathological physiology with a master's degree in medical education. Full and consulting professor, Salvador Allende Medical Sciences Faculty, Medical University of Havana, Cuba.

Lourdes G. Arencibia Flores, physician specializing in normal and pathological physiology with a master's degree in medical education. Associate professor, Salvador Allende Medical Sciences Faculty, Medical University of Havana, Cuba.

Mayra Garí Calzada, physician specializing in human embryology. Full professor and senior researcher, Faculty of Health Sciences, Walter Sisulu University, Mthatha, Eastern Cape, South Africa.

Submitted: January 16, 2012

Approved for publication: June 28, 2012

Disclosures: None 